\title{
TECHNOLOGY OF ARTIFICIAL DEPOSIT PRESERVATION AT THE KURSK MAGNETIC ANOMALY
}

\author{
Maria Anatolievna Pashkevich ${ }^{1}$, Tatyana Anatolyevna Petrova ${ }^{1}$ \\ 1 Saint-Petersburg Mining University, $21^{\text {st }}$ Vasilevsky Ostrov, Line 2, Saint Petersburg, 199106, Russia, e-mail: \\ mpash@spmi.ru, petrova9@yandex.ru
}

Received: 2016.06 .17 Accepted: 2016.08.08

Published: 2016.09.20

\begin{abstract}
An evaluation of existing insulation and remediation technologies for solid mineral waste storages is carried out. Results of field observations at one of the largest tailings in Russia are given. A quality of atmospheric air, and surface and ground water are estimated in the impact areas of a magnetic separation waste storage at an iron ore deposit of the Kursk Magnetic Anomaly. An effective method of landfill's surface insulation using polymeric materials is offered. The technological insulation process by means of a self-propelled screening machine is described. The suggested method will allow preserving an artificial deposit until the time of its rational mining, stopping water and wind erosion from its surface. Environmental conditions in its location area will be improved and pollution of atmosphere, soil, and natural water will be reduced.
\end{abstract}

Keywords: waste repository; adverse impact; technogenic deposit; reclamation; conservation.

\section{INTRODUCTION}

Activities of mineral extracting and processing enterprises are associated with natural resource consumption and formation of various wastes accumulated in the natural environment. Particularly, an iron ore deposit mining leads to the annual accumulation of ca. 17.4 billion tons of solid wastes in the upper lithosphere layers [Pashkevich and Petrova, 2015]. The wastes are characterised by the substantial heavy metal content.

An iron ore processing waste storage is a research object. It is located within the Kursk Magnetic Anomaly, being one of the largest by size in Russia: the land allotment area is $22.5 \mathrm{~km}^{2}$; the effective area is $17.3 \mathrm{~km}^{2}$. The volume of annually stored ferruginous quartzite processing tailings is greater than 12 million $\mathrm{m}^{3}$. More than 300 million tons of environmentally hazardous finegrained magnetic separation wastes are accumulated in the tailings. Contamination of virtually all environmental components takes place under the influence of water and wind erosion. On the other hand, the wastes are potential mineral resources since their total iron weight fraction reaches 25 28\% [Gal'perin, 2006; Simpson, 1988].

In this regard, the main tasks of conducted research were:

- to study landscape-geochemical conditions in the tailing impact area;

- to assess and abate negative influence of wastes on atmospheric air, soil and vegetation cover, and ground water;

- to preserve a technogenic deposit from wind and water erosion aiming to prevent a potential loss of mineral raw materials.

\section{MATERIALS AND METHODS}

Wastes emerging after iron ore wet magnetic separation arrive by pipeline in the pulp form and make a technogenic dump with an area exceeding $17 \mathrm{~km}^{2}$. Observations of the dump state spent within five years shown that an area of dry erosion-prone territories reaches $30 \%$ of the total storage space. The major part of dusting territories (up to $75 \%$ ) is located in those tailing areas, 
where stockpiling is not performed over the past 5 years. Their adverse environmental impact is caused by wind dusting from dry surfaces. The reasons for this are: fine initial ore grinding (class of $0.04 \mathrm{~mm}$ makes $75 \%)$ and large (250-300 m) tailing beach width.

Field observations of dust impact on atmospheric air using portable Dust Track TSI and Dust 4RB analysers were carried out in the tailing area. Dust concentration measurements in the tailing area showed that the air dustiness at the average $7-8 \mathrm{~m} / \mathrm{s}$ wind speed and at the distance of $100 \mathrm{~m}$ from the tailings was $30-137 \mathrm{~g} / \mathrm{m}^{3}$, and at the distance of $1000 \mathrm{~m}$ it was $1.1-6.1 \mathrm{mg} / \mathrm{m}^{3}$ (Table 1). At the average $5-8 \mathrm{~m} / \mathrm{s}$ wind speed, $2.0-5.0$ fine dust tons are carried away into the atmosphere from each hectare of dry tailing surface per day, while approximately 800 fine dust tons are blown off the entire tailing surface. The conducted measurements revealed that in dry windy weather dust rises into the air and spreads to distances up to $30 \mathrm{~km}$, polluting an air basin and surrounding areas.

The dust chemical analysis conducted by the atomic absorption spectrophotometer Shimadzu AA-7000 proved that a number of potentially toxic metals [Greenwood and Earnshaw, 1997] is contained in the fugitive dust from tailings: 580 $\mathrm{ppb}$ of vanadium, $900 \mathrm{ppb}$ of titanium, $350 \mathrm{ppb}$ of zinc, and $300 \mathrm{ppb}$ of cobalt.
The tailing impact on agricultural lands leads to the greatest economic loss. Dust in amount from 1000 to 1200 tons is annually taken out from $10,000 \mathrm{~m}^{2}$ of waste technogenic deposit consisting of sandy spoils. A deposition of dust layer with the $4-5 \mathrm{~cm}$ thickness on soil surface results in a complete crops seedling destruction caused by soil composition changes [Alekseenko and Alekseenko, 2014; Il'in et al., 2003; Minkina et al., 2011; Motuzova et al., 2014; Roca et al., 2012; Syso et al., 2014]. Currently, an economic damage by soil deterioration due to the storage dusting is greater than $\$ 1000000$ annually, which is related to a land withdrawal from agricultural use and a decrease in soil fertility.

The complete composition transformation of the underlying ground water occurs due to the contaminant leaching from tailings. Ground waters discharging into surface water bodies and water courses [Puzanov et al., 2012] are a major source of their pollution (Table 2).

Fugitive dust from tailings is mainly represented by quartz and iron minerals: hematite, magnetite, and iron hydroxides (iron content in the dust is $25-30 \%$ ). Due to the ferrous ion leaching by infiltration water into the upper aquifers, losses of potential mineral raw materials occur.

In that context, a method of technogenic deposit preservation was designed to save potential

Table 1. Fugitive dust emission from tailing dump of ore mining and processing complex «Mikhailovsky GOK»: contamination distribution in atmospheric surface layer $\left(\mathrm{mg} / \mathrm{m}^{3}\right)$

\begin{tabular}{|c|c|c|c|c|}
\hline \multirow{2}{*}{$\begin{array}{c}\text { Distance from the dusting } \\
\text { source, } \mathrm{km}\end{array}$} & \multicolumn{4}{|c|}{ Dissipated dust amount at different wind speed, $\mathrm{m} / \mathrm{s}$} \\
\cline { 2 - 5 } & 3.5 & 5.3 & 6.7 & 7.8 \\
\hline 0.5 & 0.016 & 0.18 & 4.85 & 26.6 \\
\hline 1.0 & 0.007 & 0.08 & 1.92 & 5.82 \\
\hline 1.5 & 0.004 & 0.05 & 1.03 & 2.81 \\
\hline 2.0 & 0.003 & 0.02 & 0.52 & 1.72 \\
\hline 3.0 & 0.002 & 0.02 & 0.33 & 1.06 \\
\hline 4.0 & 0.002 & 0.009 & 0.19 & 0.81 \\
\hline 5.0 & 0.001 & 0.006 & 0.15 & 0.29 \\
\hline 10.0 & 0.001 & 0.003 & 0.07 & \\
\hline
\end{tabular}

Table 2. The chemical composition of ground water from observation well: the impact of solid wastes on groundwater $\left(\mathrm{mg} / \mathrm{dm}^{3}\right)$ near ore mining and processing complex "Mikhailovsky GOK" (50 $\mathrm{m}$ from the tailing boundary)

\begin{tabular}{|l|c|c|c|c|c|c|c|}
\hline \multicolumn{1}{|c|}{ Chemical element } & $\mathrm{Fe}(\mathrm{II})$ & $\mathrm{Mn}$ (II) & $\mathrm{Cu}$ (II) & $\mathrm{Ni}$ (II) & $\mathrm{Pb}(\mathrm{II})$ & $\mathrm{Zn}$ (II) & $\mathrm{Cr}$ (III) \\
\hline $\begin{array}{l}\text { Background concentration } \\
\text { in ground water }\end{array}$ & 6.5 & 0.09 & 0.004 & 0.02 & 0.02 & 0.04 & 0.002 \\
\hline $\begin{array}{l}\text { Actual concentration in } \\
\text { waste water }\end{array}$ & 1234.0 & 21.80 & 1.920 & 1.62 & 0.15 & 25.20 & 0.240 \\
\hline $\begin{array}{l}\text { Maximum permissible } \\
\text { concentration in water }\end{array}$ & 0.3 & 0.10 & 1.000 & 0.10 & 0.10 & 1.00 & 0.500 \\
\hline
\end{tabular}


resources and to reduce an impact of processing wastes on atmospheric air, plant and soil cover, and natural waters [Bezel' and Zhuikova, 2007; Bolshunova et al., 2014; Minkina et al., 2014; Pashkevich et al., 2015; Timofeev et al., 2016; Zhuikova et al., 2015]

The choice of tailing conservation method and technologies based on it was determined by the totality of physical and chemical parameters of wastes and shielding materials, opportunities of the method applied, and economic indicators of existing waste screening technologies. The technogenic deposit preservation by screening is currently performed in three main ways [Conner and Hoeffner 1998; Pashkevich 2015; Raj et al. 2005; Rechard 2000; Smith 1985]:

1) The waterproofing layer formation based on natural clays.

2) The waterproofing layer formation based on polymeric sheets (geomembranes).

3) The waterproofing layer formation based on oil production wastes.

Despite the fact that all the currently used methods provide better protection of ground water, each of them has a number of disadvantages [Peacock, 2000].

The waterproofing method with the application of natural clays as the impermeable layer is extremely labour-intensive. It requires large quantities (from 0.35 to $1.0 \mathrm{~m}^{3} \cdot \mathrm{m}^{-2}$ ) of the applied material, and its preliminary processing for the subsequent coating. Clay minerals are exposed to the surface environment changes (seasonal temperature changes, solar radiation, drying out in a low-flow period, and acid rains). A combined effect of these two factors leads to the structural change of a waterproofing material, followed by the gradual strength reducing and its consequent destruction.

The waterproofing method with geomembranes is rather time-consuming, as well as expensive: the geomembrane price is up to $\$ 10$ per $1 \mathrm{~m}^{2}$. Moreover, the formation of such a coating implies stitching of already finished sheet material. That is the reason of seams occurring, causing the unacceptable increased risk of the defect appearance in coating integrity under the influence of climatic, hydrographic, and technogenic factors.

The main shortcomings of the waterproofing layer forming based on oil production wastes is a material toxicity and a tendency to destruction when exposed to aggressive liquid environments forming a secondary pollution from disintegrating coating components.

Due to the listed disadvantages of foregoing methods, the need to develop a new, long-lasting, cost-effective, and environmentally sound dump reclamation and insulation technique emerged. The creation technology of waterproofing coatings based on secondary polymers with an extrusive mixture applying on the prepared surface was developed and proposed for introduction for that purpose.

The technology consists in formation of the coating that prevents an infiltration of atmospheric and waste waters from mine dumps. The infiltration is accompanied by ground water pollution with potentially toxic substances [Rikhanov et al., 2011], as well as dusting from spoil surface.

The technogenic deposit insulation at the inactive part of iron ore-preparation waste storage within the Kursk Magnetic Anomaly is performed by the waterproofing mixture processing and its installation on the prepared surface. The mixture is prepared by stirring on the application site. After that, it is loaded into the bunker of the extrusive-moulding machine and electro-thermally heated to the melting temperature $\left(180-200{ }^{\circ} \mathrm{C}\right)$. After that, by means of screw feed to an extruder, the mixture is applied in the molten form to the prepared surface by $2.0-2.5 \mathrm{~m}$ stripes, with a mutual $0.15-0.20 \mathrm{~m}$ overlapping. The overlapping of the laid polymeric mixture strips will enhance integrity of the whole coating, as well as eliminate the need for its cross-linking, in contrast to geomembrane application. A drainage $0.10-0.15 \mathrm{~m}$ thick layer of coarser sandy material is applied on the chilled surface. The works on dumping waste collecting system formation and covering with soil and vegetation layer are conducted after the application of a drainage layer

The high requirements are imposed on such coverage, both in terms of toxicological safety, and physico-mechanical properties [Spence and Shi, 2005; Tedder and Pohland, 2002]. The certain polymeric properties must be preserved for a long time at the maximum load by climatic factors, varying fairly wide.

In this regard, there was a need for a detailed destruction pattern study of the formed coating under the climatic influence and forming an optimal mixture recipe: ratios of such recyclable secondary polymers as polypropylene (PP), and high-density and low-density polyethylene (HDPE, LDPE). 
The application of waterproofing coatings on the basis of polymeric materials in various fields of human activities requires a detailed study of such material behaviour and an appropriate set of testing methods [Kalb et al. 1991; ÖzverdI and Erdem 2010]. Therefore, the temperature effect on the strength polymer characteristics was investigated not only at a constant deforming stress and bending tests, but also under the falling pendulum hit destruction or impact testing machine.

\section{RESULTS AND DISCUSSIONS}

The studies of the negative temperature effect on the strength characteristics of polymeric materials were carried out using the impact pendulum-type testing machine IT 504. The tests were conducted in accordance with GOST 4647-80 "Plastics. Method for determination of Charpy's impact strength".

Test samples were cut from the sheet material previously prepared and had geometric dimensions of $50 \times 6 \times 4 \mathrm{~mm}$. The $6 \mathrm{~mm}$ thick samples were subjected to the mechanical processing in order to achieve the established thickness standards.

The PP, LDPE, and HDPE samples were subjected to an impact load at different temperatures in the range from minus 30 to plus $60{ }^{\circ} \mathrm{C}$ with the $10{ }^{\circ} \mathrm{C}$ measurement interval. The toughness values $\left(a_{n}\right)$ were determined in the experiment, i.e. the fragility of the samples at different temperatures was actually defined. The results of this experiment are summarized in Table 3 and represented graphically in Figure 1.

As can be seen from the graphic dependence above, the PP samples have the lowest toughness figures. Such a material behaviour is determined by the high density value of the test material. A destruction of the PP samples was observed throughout the test range, with a low toughness from $2.8 \pm 0.014 \mathrm{~kJ} \times \mathrm{m}^{-2}$, at minus $30^{\circ} \mathrm{C}$

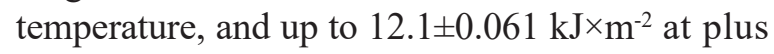
$60{ }^{\circ} \mathrm{C}$ temperature. The destruction of LDPE within the temperature range from plus 10 to $60{ }^{\circ} \mathrm{C}$ was not observed. The sample destruction was observed at the zero-value temperature with a relatively high $\left(35.4 \pm 0.177 \mathrm{~kJ} \times \mathrm{m}^{-2}\right)$ toughness index. The LDPE toughness varied slightly in the subsequent change of sample test temperature down to minus $30{ }^{\circ} \mathrm{C}$. The temperature range from 30 to $60{ }^{\circ} \mathrm{C}$, in which the sample destruction did not occur, was also noted as a result of the HDPE sample testing. As the temperature decreased from $30{ }^{\circ} \mathrm{C}$ down to the lower temperature limit of testing minus

Table 3. The results of PP, LDPE and HDPE toughness tests at different temperatures

\begin{tabular}{|c|c|c|c|c|c|c|c|c|c|c|}
\hline \multirow{2}{*}{$\begin{array}{l}\text { Sample } \\
\text { material }\end{array}$} & \multicolumn{10}{|c|}{ Toughness $\mathrm{a}_{\mathrm{n}}, \mathrm{kJ} \cdot \mathrm{m}^{-2}$ (measuring uncertainty is $\pm 0.5 \%$ ) } \\
\hline & $-30^{\circ} \mathrm{C}$ & $-20^{\circ} \mathrm{C}$ & $-10^{\circ} \mathrm{C}$ & $0^{\circ} \mathrm{C}$ & $10^{\circ} \mathrm{C}$ & $20^{\circ} \mathrm{C}$ & $30^{\circ} \mathrm{C}$ & $40^{\circ} \mathrm{C}$ & $50^{\circ} \mathrm{C}$ & $60^{\circ} \mathrm{C}$ \\
\hline PP & 2.8 & 3.6 & 5.2 & 5.7 & 7.2 & 7.5 & 7.5 & 9.6 & 10.9 & 12.1 \\
\hline LDPE & 35.1 & 35.3 & 35.3 & 35.4 & $\begin{array}{c}\text { not } \\
\text { disintegrating }\end{array}$ & $\begin{array}{c}\text { not } \\
\text { disintegrating }\end{array}$ & $\begin{array}{c}\text { not } \\
\text { disintegrating }\end{array}$ & $\begin{array}{c}\text { not } \\
\text { disintegrating }\end{array}$ & $\begin{array}{c}\text { not } \\
\text { disintegrating }\end{array}$ & $\begin{array}{c}\text { not } \\
\text { disintegrating } \\
\end{array}$ \\
\hline HDPE & 25.6 & 25.8 & 26.4 & 26.3 & 26.3 & $\begin{array}{c}\text { not } \\
\text { disintegrating }\end{array}$ & $\begin{array}{c}\text { not } \\
\text { disintegrating }\end{array}$ & $\begin{array}{c}\text { not } \\
\text { disintegrating }\end{array}$ & $\begin{array}{c}\text { not } \\
\text { disintegrating }\end{array}$ & $\begin{array}{c}\text { not } \\
\text { disintegrating }\end{array}$ \\
\hline
\end{tabular}

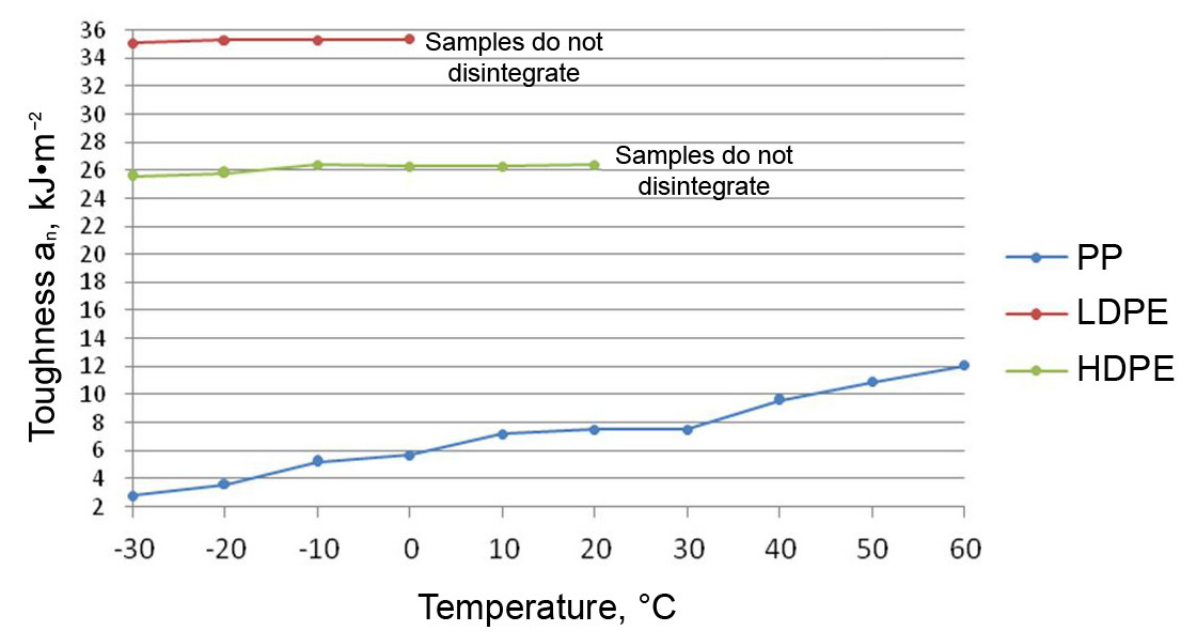

Figure 1. Toughness of polymeric material samples $\left(a_{n}\right)$ as a function of temperature 
$30{ }^{\circ} \mathrm{C}$, the HDPE samples were destroyed in the range $26.4-25.6 \mathrm{~kJ} \times \mathrm{m}^{-2}$ of toughness values with $\pm 0.5 \%$ measurement error.

The difference in toughness values of consistently tested low and high pressure polyethylenes depends on the various degrees of crystallinity of the two polymers [Glebov, Lysenko, 1979]. The content of the crystalline phase in LDPE amounts to $55-70 \%$, which determines its high elasticity, while the content of the crystalline phase in HDPE is in the range of $75-95 \%$.

Following the results of complex research, it was proved that the high and low-density polyethylenes are the most suitable materials for the formation of the waterproofing coating in the mine dump construction and their year-round operation at various temperature ranges. Polypropylene as an insulating material has an increased fragility that grows with decreasing temperature, which is an unacceptable for this material.

The preferred use of polyethylene as compared with polypropylene is confirmed also by the results of influence tests of aggressive media on the investigated materials. In particular, upon the application of equal bending loads and at the permanent contact with an alkaline solution, the PP samples have the highest tendency to cracking. Polypropylene $1 \mathrm{~mm}$ thick samples in their turn have the highest resistance to punching (compressive load application). The researches on polymer samples of 3 and $6 \mathrm{~mm}$ in thickness allow speaking about the necessity to form a waterproofing layer of more than $1 \mathrm{~mm}$ thick. The tensile characteristics of all the tested materials in this case satisfy the loads, occurring during the mine dump formation and exploitation.

The obtained results allow saying that when selecting the formed coating formulations, depending on climatic, geographical, and technological features of mineral deposits, polyisobutylene can be used as a corrective recipe component. This will improve the strength characteristics of recycled secondary polymers.

According to the research of physico-mechanical coating properties with different secondary polymer ratios, the substantiation of optimum polymeric mixture structure was carried out:

- the secondary low-density polyethylene (LDPE): 78-81 wt\%;

- the secondary high-density polyethylene (HDPE): 18-19 wt \%;

- polyisobutylene: $1-3 \mathrm{wt} \%$.

\section{CONCLUSION}

The conducted research allowed solving an actual scientific and industrial task to assess and reduce the processing waste negative impact on environmental components at «Mikhailovsky GOK». Preservation of potential mineral raw materials may be achieved by the developed method of tailing surface shielding. The proposed technology of potential technogenic deposit conservation allows:

- to increase the strength and thereby to keep a cover shape for a long term;

- to simplify and improve the coating producing manufacturability, with waterproofing properties under constant wind loads and precipitation effects, as well as in contact with cutting and piercing objects;

- to reduce a filtration rate by improving the coating anti-friction properties, increasing its density and solidity;

- to reduce the water absorption by coatings through the thermal interaction between composite material and hard mineral wastes;

- to solve the basic problem of screens, namely the destructive climatic effect;

- to reduce significantly a screening cost and to decrease an environmental pollution by using polyethylene and polypropylene wastes;

- to save valuable components contained in industrial wastes, which may be used in the future, and currently pose a disruption threat to the natural environment and human existence conditions.

\section{Acknowledgements}

The analyses were performed with the equipment of Common Use Centre of Saint Petersburg Mining University.

\section{REFERENCES}

1. Alekseenko V., Alekseenko A., 2014. The abundances of chemical elements in urban soils. Journal of Geochemical Exploration, 147, 245-249.

2. Bezel' V.S., Zhuikova T.V., 2007. Chemical pollution: Transfer of chemical elements to the aboverground phytomass of herbaceous plants. Russian Journal of Ecology, 38 (4), 238-246.

3. Bolshunova T.S., Rikhvanov L.P., Mezhibor A.M., 2014. Epiphytic lichens as indicators of air pollution in Tomsk Oblast (Russia). IOP Conference 
Series: Earth and Environmental Science, 21 (1), 12-43.

4. Conner J.R., Hoeffner S.L., 1998. A Critical Review of Stabilization/Solidification Technology. Critical Reviews in Environmental Science and Technology, 28 (4), 397-462.

5. Gal'perin A.M., Forster V., Chief H.Yu., 2006. Technogenic massifs and protection of natural resources. Vol. 1. Bulk and alluvial massifs. Publishing house of Moscow State Mining University.

6. Glebov V.D., Lysenko V.P., 1979. Calculation of the thickness of the polymer film impervious screens. Hydraulic engineering construction, 6, 17-20.

7. Greenwood N.N., Earnshaw A., 1997. Chemistry of the Elements. 2nd Edition. Butterworth-Heinemann.

8. Il'in V.B. et al., 2003. Background concentrations of heavy metals in soils of southern Western Siberia. Eurasian Soil Science, 36 (5), 494-500.

9. Kalb P.D., Heiser J.H., Colombo P., 1991. Longterm durability of polyethylene for encapsulation of low-level radioactive, hazardous, and mixed wastes.

10. Minkina T. et al., 2014. Accumulation and distribution of heavy metals in plants within the technogenesis zone. Environmental Engineering and Management Journal, 13 (5), 1307-1315.

11. Minkina T. et al., 2011. Transformation of heavy metal compounds during the remediation of contaminated soils. Agriculturae Conspectus Scientificus, 76 (1), 19-25.

12. Motuzova G.V. et al., 2014. Soil contamination with heavy metals as a potential and real risk to the environment. Journal of Geochemical Exploration, 144 (PB), 241-246.

13. ÖzverdI A., Erdem M., 2010. Environmental risk assessment and stabilization/solidification of zinc extraction residue: I. Environmental risk assessment. Hydrometallurgy, 100 (3-4), 103-109.

14. Pashkevich M.A. et al. Method for preservation and isolation anthropogenic deposits. Patent № RU2547869. Date of filing: 08.11.2013. Date of publication: 10.04.2015, Bull. 10.

15. Pashkevich M.A., Alekseenko A.V., Vlasova E.V., 2015. Biogeochemical and geobotanical assessment of marine ecosystems conditions (Novorossiysk city). Water and Ecology, 2015 (3), 67-80.
16. Pashkevich M.A., Petrova T.A., 2015. New isolation materials for technogenic deposits conservation. Obogashchenie Rud 6, 46-49.

17. Peacock A., 2000. Handbook of Polyethylene: Structures: Properties, and Applications, CRC Press.

18. Puzanov A.V., Baboshkina S.V., Gorbachev I.V., 2012. Characteristics of heavy metal migration in the natural-anthropogenic anomalies of the NorthWestern Altai. Geochemistry International, 50 (4), 358-366.

19. Raj D.S.S. et al., 2005. Stabilisation and solidification technologies for the remediation of contaminated soils and sediments: an overview. Land Contamination, Reclamation, 13 (1), 23-48.

20. Rechard R.P., 2000. Historical background on performance assessment for the Waste Isolation Pilot Plant. Reliability Engineering, System Safety, 69 (1-3), 5-46.

21. Rikhanov L.P. et al., 2011. Trace elements in human organs and tissues and their significance for environmental monitoring. Geochemistry International, 49 (7), 738-742.

22. Roca N., Pazos M.S., Bech J., 2012. Background levels of potentially toxic elements in soils: A case study in Catamarca (a semiarid region in Argentina). Catena, 92, 55-66.

23. Simpson H.E., 1988. Artificial deposits and modified land. In: Encyclopedia of Earth Sciences. General Geology. Springer US.

24. Spence R.D., Shi C., 2005. Stabilization and Solidification of Hazardous, Radioactive, and Mixed Wastes, Taylor Francis.

25. Syso A.I. et al., 2014. Elemental chemical composition of soils and plants in Western Taimyr. Contemporary Problems of Ecology, 7 (6), 636-642.

26. Tedder D.W., Pohland F.G. (Eds.), 2002. Emerging Technologies in Hazardous Waste Management 8, Boston: Kluwer Academic Publishers.

27. Timofeev I.V., Kosheleva N.E., Kasimov N.S., Gunin P.D., Enkh-Amgalan S., 2016. Geochemical transformation of soil cover in copper-molybdenum mining areas (Erdenet, Mongolia). Journal of Soils and Sediments. 16 (4), 1225-1237.

28. Zhuikova T.V. et al., 2015. Specific features of soils and herbaceous plant communities in industrially polluted areas of the Middle Urals. Russian Journal of Ecology, 46 (3), 213-221. 